\title{
Retail Development under the Conditions of Globalization
}

\author{
O. Chkalova and M. Efremova
}

\begin{abstract}
Globalization of economic processes requires the study of the patterns of trade development in the world's business space. The purpose of this research is to study the trends in the development of retail trade chains, giving evidence of globalization processes in retail. The object of research are international retail trade chains, included in TOP-250, according to Deloitte. It identifies the trends, issues and prospects of development of the largest retail chains and estimates the level of global activity of retail chains based on the scale of their operations in international markets: the number of countries present, revenue from international operations, the development of private labels. A more detailed research is carried out on the example of the Russian market of retail trade chains.
\end{abstract}

Index Terms-Globalization, retail chains, retail market, retail revenue.

\section{INTRODUCTION}

Globalization processes are an important trend in the modern world, which affects all business sectors, including retail [1]-[3]. For a long time retail was seen just as a technological structure ensuring that manufacturers' goods reach the consumer, and the globalization processes did not have any impact on it. For instance, in 1997 there were no retail companies in the list of 200 biggest companies in Russia, and in the US among 100 biggest companies there were only 3 retail companies. As retail chains started to develop, the situation has changed dramatically [4]-[6]. Retail has become one of the leading business sectors. So, retail contribution to GDP in many countries is bigger than that of other business sectors: in the US it accounts for $27 \%$ of GDP, in Russia - for $19,7 \%$. Today retail, due to a range of peculiarities, connected with the development of retail chains, is in the center of globalization processes. The purpose of this research is to identify the peculiarities of development of retail chains providing evidence of globalization processes in retail.

\section{LITERATURE REVIEW}

The main characteristic feature of the development of world economy at the end of the 20th and the beginning of the 21 st century is the increasing globalization process, the essence of which is demonstrated by the transnationalization of international economic relations [7], [8]. Theodore Levitt, an American scientist, is considered the founder of the globalization theory after the publishing of his book called

Manuscript received June 9, 2015; revised August 10, 2015.

The authors are with Lobachevsky State University of Nizhni Novgorod, Russia (e-mail: ochkalova@fup.unn.ru).
"The Globalization of Markets" in 1983 [7]. A specific peculiarity of the phenomenon of globalization is that it is a many-sided process, which is reflected in the definition of globalization as an ideological, economic and social issue [9]. The globalization proccess embraces nearly all business sectors, but has unprecedented influence on retail in the first place. The main initiators and the result of retail development under the conditions of globalization are retail trade chains [10]-[13].

The development of retail trade chains under the conditions of globalization is reflected in the growing scale of business, larger enterprises, blurred territorial borders for business while preserving national identity, transnational operations based on the use of networking technologies, which goes in line with the establishment of a new world economy $[14,15]$.

Modern globalization processes are unfolding with a different degree of intensity in different regions of the world and between different groups of countries. The most active development of these processes is taking place in Europe. Today there is also a growing global activity of retail trade chains from developing continents - Africa and the Middle East, Latin America, Asia-Pacific regions [16].

\section{RESEARCH METHODOLOGY}

The methodological basis of this research comprises the reports of a British consulting and audit company «Deloitte Touche Tohmatsu Limited" (DTTL), analytics agencies and consulting companies A.T.Kearney, A.C.Nielsen, INFOLine, RBK, Hybris, KPMG, Grinderr.

\section{ANALYSIS OF RESEARCH RESULTS OR SCIENTIFIC PROBLEM}

In 2013 the retail market in European countries was valued at 3,1 trillion euros, in the US - at 3 trillion euros. Here are the top three European countries according to the volume of retail trade: $1^{\text {st }}$ place - Russia (465 billion euros), $2^{\text {nd }}-$ France (417 billion euros), $3^{\text {rd }}-$ Germany (412 billion euros).

The main peculiarity of development of the largest retail trade chains under the conditions of globalization is the increasing scale of their business activities. In 2013, 250 world's largest retailers included in the rating of Global Powers of Retailing by an international consulting company Delloitte had a revenue of about 4,355 trillion dollars, 10 largest retailers $-1,295$ trillion dollars, or nearly $30 \%$ of the total revenue. The downward trend in the growth rate of net retail revenue of top 250 retailers which started in 2011, continued in 2013.

Despite the continuing downward trend in the growth rate, approximately $80 \%$ of the companies under consideration (199 out of 250) showed a rise of retail revenue in the 
financial year 2013. 10\% of all the revenue belongs to the largest retail leader in the world - Wal-Mart (Table I).

The table shows that out of the world's top 10 largest retailers, 5 are American retail chains (Wal-Mart Stores, Costco Wholesale Corporation, The Kroger Co, The Home
Depot, Target Corporation), 3 are German retailers (Schwarz Unternehmens Treuhand KG, Metro AG, Aldi Einkauf GmbH \& Co), 1 is from France (Carrefour S.A) and 1 from U.K (Tesco PLC). The most successful large retail chains in 2013 were companies which belong to the FMCG Sector.

TABLE I: TOP 10 RETAILERS WORLDWIDE, 2013*

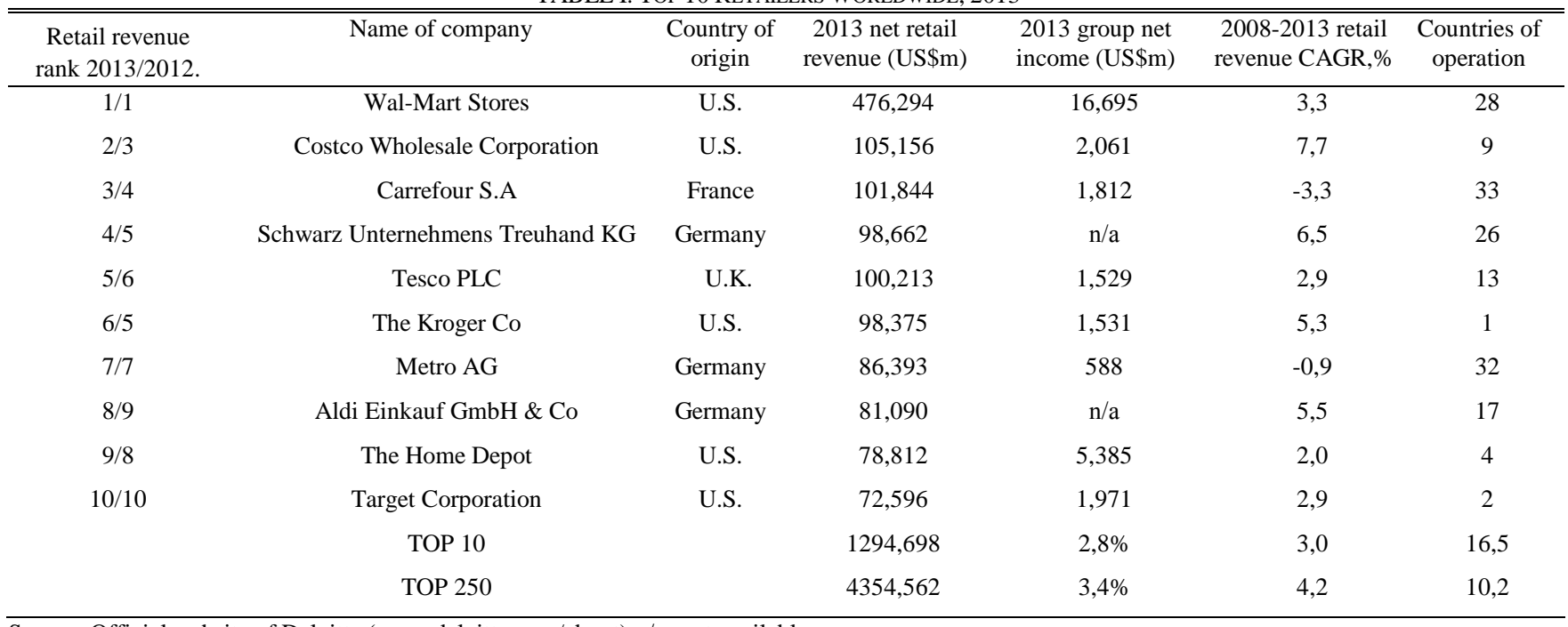

Source: Official website of Deloitte (www.deloitte.com/about) n/a- not available

TABLE II: INDICATORS OF WORLDWIDE RETAIL, 2006-2013*

\begin{tabular}{|c|c|c|c|c|c|c|c|c|}
\hline Indicators & 2006 & 2007 & 2008 & 2009 & 2010 & 2011 & 2012 & 2013 \\
\hline Retail revenue, (US\$tril) & 3,246 & 3,619 & 3,818 & 3,763 & 3,940 & 4,271 & 4,287 & 4,355 \\
\hline Average retail revenue of Top 250 company, (US\$mil) & 12,96 & 14,87 & 15,29 & 15,05 & 15,76 & 17,08 & 17,15 & 17,42 \\
\hline Composite net profit margin, $\%$ & 3,6 & 3,7 & 2,4 & 3,1 & 3,8 & 3,8 & 3,1 & 3,4 \\
\hline
\end{tabular}

*Source: Official website of Deloitte (www.deloitte.com/about)

The grand scale of business of transnational retail trade chains can be judged by the principal performance indicators of 250 world's largest retail trade chains, published by DTTL (Table II).

Active globalization of retail and its entrance to new markets is a very important area of focus for transnational retail corporations and a leading trend in their development in the modern world, which by and large signifies the intensification of the globalization process in the world's economy. The average number of countries presence in TOP-10 is 16,5 , in TOP-250 - 10,2. The expansion of geographical presence of worldwide retail chains is confirmed by the increased average number of countries of operation, which has grown from 2006 till 2013 by 4 countries and accounted for 10,2 in 2013 (Fig. 1).

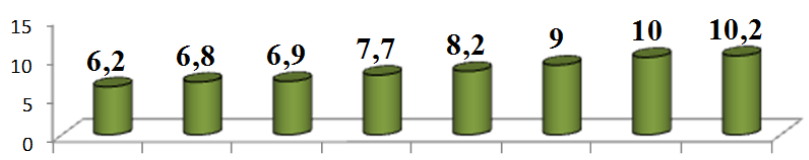

20062007200820092010201120122013

Fig. 1. Average number of countries of operation of the largest retail chains from 2006 till 2013.

Global expansion gives opportunities to large transnational retail chains to increase the volume of retail sales in developing countries and create large-scale controlled global regional supply chains.

Territorial expansion has led to an increase in revenue of the largest retail chains coming from international operations.
Thus, about $40 \%$ of retail revenue of European retail chains during the period under consideration has come from operations outside national borders. (Table III).

\begin{tabular}{lcccc} 
TABLE III: LEVEL OF GLOBALIZATION BY REGION / COUNTRY, 2009/2013* \\
\hline \hline \multicolumn{1}{c}{ Region/country } & \multicolumn{2}{c}{ Average of countries } & \multicolumn{2}{c}{$\begin{array}{c}\text { \% retail revenue from } \\
\text { foreign operations }\end{array}$} \\
& 2009 & 2013 & 2009 & 2013 \\
\hline Top -250 & 6,8 & 10,2 & 21,3 & 24,2 \\
Africa/Middle East & 9,0 & 12,1 & 12,5 & 25,1 \\
Asia/Pacific & 3,7 & 5,4 & 12,3 & 14,0 \\
Japan & 2,8 & 3,9 & 10,0 & 9,4 \\
Europe & 11,1 & 16,2 & 35,1 & 38,6 \\
France & 18,9 & 28,6 & 35,6 & 43,6 \\
Germany & 13,8 & 15,4 & 41,8 & 45,4 \\
U.K & 10,0 & 16,1 & 19,0 & 21,5 \\
Latin America & 1,6 & 2,3 & 9,9 & 22,9 \\
North America & 3,9 & 7,8 & 11,8 & 14,7 \\
U.S. & 5,1 & 8,5 & 11,7 & 15,4 \\
\hline \hline S Source: developed by authors
\end{tabular}

* Source: developed by authors

The analysis of research results shows that the US has the largest number of retail trade chains, represented in TOP-250 - 79 retailers. The company share in TOP-250 accounts for $31,6 \%$, the revenue share - for $41,9 \%$. High global activity is demonstrated by European companies. 90 largest retail trade chains of European origin are represented in the TOP-250 rating. There has been a growing trend in the global activity of retail trade chains from countries of developing continents Africa and the Middle East, Latin America, Asia-Pacific regions (Table IV). 
TABLE IV: REGION / COUNTRY PROFILES, TOP-250, 2013*

\begin{tabular}{lllll}
\multicolumn{5}{c}{ TABLE IV: REGION / COUNTRY PROFILES, TOP-250, 2013* } \\
\hline \hline Region & Companies & $\begin{array}{l}\text { Average } \\
\text { retail } \\
\text { revenue } \\
\text { (US\$mil) }\end{array}$ & $\begin{array}{l}\text { Share of } \\
\text { TOP 250 } \\
\text { Companies, }\end{array}$ & $\begin{array}{l}\text { Share of } \\
\text { TOP 250 } \\
\text { Revenue, } \\
\%\end{array}$ \\
\hline TOP 250 & 250 & 17,418 & 100,0 & 100,0 \\
Africa/Middle & 7 & 6,384 & 2,8 & 1,0 \\
East & & & & \\
Asia/Pacific & 55 & 11,121 & 22,0 & 14,0 \\
Japan & 31 & 9,835 & 12,4 & 7,0 \\
Other & 24 & 12,782 & 9,6 & 7,0 \\
Asia/Pacific & & & & \\
Europe & 90 & 18,840 & 36,0 & 38,9 \\
France & 14 & 29,279 & 5,6 & 9,4 \\
Germany & 17 & 27,060 & 6,8 & 10,6 \\
U.K. & 14 & 19,391 & 5,6 & 6,2 \\
Other Europe & 45 & 12,316 & 18,0 & 17,7 \\
Latin America & 10 & 7,757 & 4,0 & 1,8 \\
North America & 88 & 21,875 & 35,2 & 44,2 \\
U.S. & 79 & 23,108 & 31,6 & 41,9 \\
Canada & 9 & 11,052 & 3,6 & 2,3 \\
\hline \hline Official webse & & & & \\
\hline
\end{tabular}

* Official website of Deloitte (http://www.deloitte.com/about)

As for the peculiarities of development of Russian retail chains, which appeared on the market twenty years ago have gone a difficult way from establishing to the opportunity of becoming competitive in the global economy. The six largest chains of Russia - Magnit, X5 Retail Group (Pyatyorochka, Perekryostok, Karusel chains), Dixy, M.Video, O'key, Lenta - have been present in the Global Powers of Retailing rating by DTTL for a few years now. Every year these chains are developing more and more effectively: thus, Magnit has moved from the $124^{\text {th }}$ place in 2010 to the $55^{\text {th }}$ in 2013 , X5 Retail Group occupied the $83^{\text {rd }}$ place in 2010, and in 2013 it was the $58^{\text {th }}$. In 2012 Dixie entered the list of largest world's retailers, occupying the 192th place. In 2013 it moved to the $166^{\text {th }}$ place. Two companies, O'key and Lenta in 2013 were first represented in this rating (their positions accordingly the $196^{\text {th }}$ and the $206^{\text {th }}$ ) (Table V).

TABLE V: POSITIONS OF DOMESTIC RETAIL CHAINS IN THE WORLD RANKING TOP-250, 2013*

\begin{tabular}{|c|c|c|c|c|}
\hline \multicolumn{2}{|c|}{ TOP- 250 Rank } & \multirow[t]{2}{*}{ Name of company } & \multicolumn{2}{|c|}{$\begin{array}{c}\text { Indicators for the } 2013 \\
\text { fiscal year ending June } 2014 \\
\text { (US\$mil) }\end{array}$} \\
\hline 2013 & 2012 & & Revenue & Net profit \\
\hline 55 & 65 & $\begin{array}{l}\text { Open Joint Stock } \\
\text { Company Magnit }\end{array}$ & 18197 & 1118 \\
\hline 58 & 58 & $\begin{array}{l}\text { X5 Retail Group } \\
\text { N.V. }\end{array}$ & 16785 & 345 \\
\hline 166 & 192 & OJSC Dixy Group & 5628 & 96 \\
\hline 192 & 211 & $\begin{array}{l}\text { OJSC «Company } \\
\text { M.Video» }\end{array}$ & 4657 & 180 \\
\hline 196 & - & Lenta Group & 4539 & 223 \\
\hline 206 & - & O'Key Group S.A. & 4387 & 157 \\
\hline
\end{tabular}

* Source: Official website of Deloitte (www.deloitte.com/about)-Access mode:http://www2.deloitte.com/content/dam/Deloitte/global/Documents/ Consumer -Business/dttl-CB-GPR14STORES.pdf

The six retail chains mentioned are among the TOP-50 fastest developing companies of the world, a rating presented by DTTL every year. The selection criterion is the growth rate of average annual revenue (Table VI).

TABLE VI: POSITIONS OF DOMESTIC RETAIL CHAINS IN THE WORLD

\begin{tabular}{|c|c|c|c|c|}
\hline $\begin{array}{l}\text { Top-50 } \\
\text { Rank }\end{array}$ & Name of company & $\begin{array}{l}\text { Retail } \\
\text { revenue } \\
\text { CAGR }\end{array}$ & $\begin{array}{l}\text { Retail } \\
\text { revenue } \\
\text { growth }\end{array}$ & $\begin{array}{l}\text { Net profit } \\
\text { margin }\end{array}$ \\
\hline 9 & $\begin{array}{l}\text { OJSC Dixy } \\
\text { Group }\end{array}$ & 30,2 & 22,8 & 1,7 \\
\hline 12 & $\begin{array}{l}\text { Open Joint Stock } \\
\text { Company Magnit }\end{array}$ & 27,9 & 26,2 & 6,1 \\
\hline 16 & Lenta Group & 23,2 & 31,3 & 4,9 \\
\hline 20 & $\begin{array}{l}\text { O'Key Group } \\
\text { S.A. }\end{array}$ & 22,3 & 18,8 & 3,6 \\
\hline 31 & $\begin{array}{l}\text { OJSC «Company } \\
\text { M.Video» }\end{array}$ & 16,8 & 10,8 & 3,9 \\
\hline 35 & X5 Retail Group & 15,0 & 6,3 & 2,1 \\
\hline
\end{tabular}

* Source: Official website of Deloitte (www.deloitte.com/about)-Access mode:http://www2.deloitte.com/content/dam/Deloitte/global/Documents/C onsumer-Business/dttl-CB-GPR14STORES.pdf

Dixy retail chain has demonstrated the highest growth rate among the national companies: it has occupied the $9^{\text {th }}$ place in that list, its average annual revenue increase from 2008 till 2013 being 30,2\%.

Growth and consolidation of retail business is not only taking place within the national economy, but is also acquiring a global nature in the worldwide economic business space. The share of four-five largest retail chains in Great Britain and France accounts for about $80 \%$ of sales. In Norway the concentration ratios of five largest chains reaches approximately $95 \%$ of consumer market. On average, in the countries with developed market economy, retail trade chains control $60-90 \%$ of the consumer market. On the consumer markets of eastern European countries (now members of the EU) the level of consolidation is lower compared to the average European level, due to the fact that small specialized stores have retained their position. The degree of consolidation in Russia has not yet reached such levels, but it has been growing steadily. By the end of 2014, the degree of consolidation on the Russian FMCG market of 8 largest retail trade chains accounted for 20,8\% (Table VII).

The analysis of performance of eight largest Russian retail chains shows that there is no absolute market leader for FMCG yet. There is fierce competition for leadership between two largest retailers, Magnit and X5 Retail Group. Since it was established in 2006 and up to 2013, X5 Retail Group was overtaking Magnit in retail revenue. In the first quarter of 2013 Magnit's retail revenue increased by 30,44\%, whereas that of X5 Retail Group rose only by $8,1 \%$, which allowed Magnit to overtake the competitor. This has been a continuous trend. Magnit's retail revenue CAGR 2014/2013 was $31,6 \%$, that of X5 Retail Group - 18,6\%. Market share: Magnit - 6,2\%, X5 Retail Group - 5,1\%.

According to another important indicator, shopping capacity, Magnit overtakes X5 Retail Group, just like in 2011. By the beginning of 2012, Magnit's shopping capacity reached 1,97 million square metres, whereas its competitor had 1,73 million square metres. In 2012 Magnit's shopping capacity already reached 2,55 million square metres, increasing the gap between the competitors. The average 
growth rate of Magnit's shopping capacity during the years 2010-2014 accounted for nearly 158\%, while X5 Retail Group increased its shopping capacity by $121,8 \%$. The gap between the retailers is even larger in terms of capitalization: the investors of the London Stock Exchange rate Magnit five times higher than X5 Retail Group - \$30,12 billion and \$5,9 billion accordingly. Although the retailers mentioned above are competitors, they have diametrically opposed development strategies. Magnit prefers organic growth in the form of opening its own convenience stores and hypermarkets. This retail chain develops in all regions, particularly in medium-size cities. This retailer is rather conservative about debt load and enthusiastically involves its stock on the stock exchange in order to maintain the amount of debt on an acceptable level. X5 Retail Group mostly develops in large cities (Moscow, St. Petersburg and the Central Region), particularly in an inorganic way through merges and takeovers.

TABLE VII: INDICATORS OF ECONOMIC CONSOLIDATION FMCG RETAIL CHAINS IN RUSSIA*

\begin{tabular}{|c|c|c|c|c|c|}
\hline $\begin{array}{l}\text { Retail revenue } \\
\text { rank }\end{array}$ & Retailer & $\begin{array}{l}\text { Retail revenue } 2014 \text { (bln } \\
\text { RUB) }\end{array}$ & $\begin{array}{c}\text { Retail revenue CAGR } \\
2014 / 2013, \%\end{array}$ & $\begin{array}{c}\text { Share of turnover } \\
\text { among top } 8 \text { players }\end{array}$ & Market share, $\%$ \\
\hline 1 & Magnit, PAO & 762,7 & 31,6 & 29,1 & 6,2 \\
\hline 3 & Auchan Group & 391 & 36 & 15 & 2,9 \\
\hline 4 & OJSC Dixy Group, GK & 227,1 & 26,9 & 8,7 & 1,8 \\
\hline 6 & Lenta Group, LTD & 194 & 34,4 & 7,4 & 1,57 \\
\hline 7 & O'Key Group S.A., GK & 151,87 & 8,9 & 5,8 & 1,2 \\
\hline 8 & Maria-Ra, GK & 57,6 & 14,3 & 2,2 & 0,46 \\
\hline
\end{tabular}

*Source: developed by authors

Another reason for Magnit's success is a well-built logistics system: from investing into distribution centres and vehicle park to direct import operations. Magnit has the biggest vehicle park among competition - 3906 vehicles (X5 Retail Group has 1300 vehicles), which allows to decrease transport costs and nearly eliminate losses during transportation. A lot of attention is paid to cooperation with local producers and suppliers, which allows to quickly deal with the issues connected with providing store chains with fresh goods of local produce.

The leading retail chains organize their own manufacturing of private labels, perform direct supplies of goods from the markets of developing countries and open their own production facilities in these countries, which allows world's leading retailers to maintain reasonable prices for their products and stay in price competition with specialized retailers. A trend towards private label manufacturing demonstrates that international supplies are acquiring a more and more intra-firm nature of trade between different divisions of transnational corporations in different countries, and their activities are gradually turning the world economy into a single market of products, services, capital and knowledge. According to Nielsen Agency, the growth rate of product sales under private labels is on average twice higher than the growth rate of independent manufacturers' product sales. In the sales turnover of the largest chains, the share of sales of private label products fluctuates from 12 to $98 \%$. Thus, in the turnover of the Auchan chain the private labels' share reaches $25 \%$, for Carrefour that is $33 \%$, for Wall-Mart $40 \%$, for Tesco $-45 \%$, for Sainsbury $-60 \%$, for Aldi $-98 \%$.

According to the marketing agency Grinderr, the top private labels in Russia are X5 Retail Group (17\% retail revenue), Maria-Ra (16\%), Magnit (11\%), and Dixy Group $(10,5 \%)$. The most efficient company in terms of private labels development is Maria-Ra. Under 31 private label, the chain sells more than 700 goods in various food and non-food segments. This kind of development strategy allows this retail chain to compete successfully with other companies and to occupy the $8^{\text {th }}$ place among the top Russian retailers in a short period of time.

The peculiarities of development of the largest retail chains which have been identified outline the general trends in retail development under the conditions of globalization.

\section{CONCLUSIONS AND FURTHER RESEARCH}

The development of trade under the conditions of globalization is connected with creating retail trade chains, working outside their "ethnic" motherland. For instance, out of 250 largest retail trade chains in 2013, 195 companies, or $65,2 \%$, operated in more than one country of the world. The share of international operations is $24,3 \%$ of the total revenue from retail sales. In 2013, the average number of countries where the largest retail trade corporations operated was 10,2.

Global expansion gives large transnational retail chains an opportunity to increase the amount of chain retailing in developing countries, create large-scale controlled global regional supply chains. As a result, leading retail trade chains' operations have a great impact on the forming of world and national markets, define the level of competition on them and have a wide geographic span.

A the same time, the development of large retail trade chains has a negative impact on small businesses. Under the conditions of consolidation of the retail sector, small businesses cannot compete with large chains and have to withdraw from the market. Thus, as seen from the overall pattern of business types in Russia in 2013, there was a decrease in the number of small businesses in retail from $39,3 \%$ in 2012 to $36,6 \%$.

Taking into account the social and economic importance of small businesses in the retail sector, in various countries of the world the development of small businesses in competition 
with retail trade chains is regulated.

Studying these issues, finding a compromise for the development of large retail chains and small retailers should become a primary focus of scientific research.

\section{REFERENCES}

[1] J. Dawson, "Scoping and conceptualizing retailer internationalization," Journal of Economic Geography, vol. 7, pp. 373 $-397,2007$.

[2] P. Hugill, "The geostrategy of global business: Wal-mart and its historical forbears," in Wal-Mart World, S. Brunn, Ed. New York, Routledge, 2006, pp. 3-14.

[3] R. E Miles and C. C. Snow, "Network organizations: New concepts for new forms," California Management Review, vol. 28, no. 3, pp. 62-73, 1986

[4] R. E Miles and C. C. Snow, "Network organizations: New concepts for new forms," California Management Review, vol. 28, no. 3, pp. 62-73, 1986

[5] N. Wrigley, "The globalization of retail capital: Themes for economic geography," Journal of Economic Geography, vol. 6, pp. 124-145, 2006.

[6] N. Wrigley, N. M. Coe, and A. Currah, "Globalizing retail: Conceptualizing the distribution-based transnational corporation (TNC)," Progress in Human Geography, vol. 29, no. 4, pp. 437-457, 2005.

[7] T. Levitt, "The Globalization of Markets," Harvard Business Review, vol. 61, pp. 92-102, May-June 1983.

[8] M. Porter, Competition in Global Industries, Harvard Business School Press, Cambridge, MA.

[9] P. Kotler, L. Fahey, and S. Jatusripitak, The New Competition, Prentice-Hall: Englewood, 1985.

[10] N. Alexander and A. M. Doherty, International Retailing, Oxford, New York: Oxford University Press, 2009, chs. 3-5.

[11] W. E. Baker, "Floor trading and crowd dynamics," in The Social Dynamics of Financial Markets, P. A. Adler and P. Adler, Eds. Greenwich, CT: JAI Press., 1984, pp. 107-128.
[12] S. L Burt, J. Dawson, and L. Sparks, "Failure in international retailing: Research propositions," International Review of Retail and Distribution Management, vol. 13, no. 4, pp. 344-373, 2003.

[13] J. H. Dyer and H. Singh, "The relational view: Cooperative strategy and sources of interorganizational competitive advantage," Academy of Management Review, vol. 23, no. 4, pp. 660-679, 1998.

[14] C. Bianchi, "An institutional perspective on retail internationalization success," International Review of Retail, Distribution and Consumer Research, vol. 14, pp. 149-169, 2004.

[15] J. A Dawson and M. Mukoyama, "Concepts, dimensions and measurements of the retail internationalization process," presented at Society for Asian Research in Distribution Management Seminar, Kobe, Japan, November 2003.

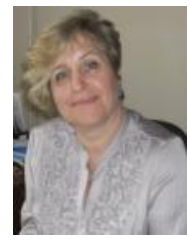

Olga Chkalova got her $\mathrm{PhD}$ degree in economics. Her dissertation is called "Formation and development of retail networks in metropolitan areas".

She is a professor, the head of Department of Trading business Lobachevsky State University, Central Russia. She has authored or co-authored over 80 publications, mainly in the fields of strategic management and marketing of retail, client-oriented development of services. Several courses she has taught include Trading business and Strategy of development of trade networks.

Prof. Chkalova has had practical experience in retail for over 10 years. She is a consultant of retail business in the organization and development of commercial enterprises.

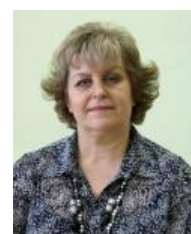

Marina Efremova got her $\mathrm{PhD}$ degree in economics, management of services. She is a professor, the head of chair "Service and tourism" at the Lobachevsky State University of Nizhni Novgorod, Russia.

She has authored or co-authored about 100 publications, mainly in the fields of marketing and management of services (trade, tourism, hotel business) She has practical experience in Chamber of Commerce, Center of Trade Services Certification, Russia. 